\title{
Interest group impact on E-health implementation in Latvia
}

\author{
I. Bikava and I. Kreituse \\ Rīga Stradiņš University, Riga, Latvia
}

\begin{abstract}
Democratic state governance should provide the society with mechanisms to impact policy development and implementation. Society members are presented by interest groups that can use internal and external ways to have impact on the government and reform implementation processes.

This article represents research that was made on E-health implementation in Latvia - identifying main obstacles and reasons of delayed implementation, and analyses active interest groups and their impact on the implementation process.

The research results showed that the main reason of delayed implementation was poor governance from the responsible authority and lack of interest group involvement in the reform development and implementation process.

Key words: E-health; interest groups; healthcare reforms; change implementation.
\end{abstract}

\section{Introduction}

Since 1991 different reforms in healthcare system in Latvia were planned and carried out with the aim to change previously existing system and to create a new system - modern, effective and accessible to citizens.

Democratic state governance requires society participation in the decision making and reform implementation process. Citizen activity and engagement in political processes are promoted to improve development of a civil society. Since 2005 society involvement is favoured not only by changes in the jurisdiction, but also by providing different sources of funding available to NGO $[1,2]$.

According to Interest Group theory - organised groups or individuals ensure mediator role between the society and state and provide the opportunity to participate in policy making and implementation [3]. According to Lobbying theory there are two ways how interest groups can influence processes: internally - in cooperation with the authority to share their knowledge and best practice to gain better results for the whole society. Or externally - through demonstrations, protests or raising alarm and pressure in the society, block or delay implementation of reforms $[4,5]$.

Interest groups acting in the healthcare sector are as follows: the dominating are different organizations of doctors and medical specialists; the second interest group endowed with most of resources - pharmacy and medical equipment manufacturers; the 
third is healthcare institutions - hospitals, ambulatory care centres, General Practitioners (GP); the fourth - patient associations and the last - state regulatory organizations $[6,7]$.

The aim of the work was to conduct research on E-health implementation process in Latvia from 2003 till November, 2016 - to identify reasons why the reform was not implemented in the originally planned time and what impact interest groups left on the implementation process. To identify the impact of interest groups, analysis of articles from different interest groups published by news agency LETA was made.

\section{Overview of E-health implementation in Latvia}

The development of E-health as a tool that can improve healthcare system, providing effectiveness and efficiency, better accountability and necessary data for decision making processes, started in 2003 when the Ministry of Health established a group of researchers to develop guidelines of E-health implementation in Latvia [8]. On June 14, 2004 the developed guidelines were presented to the society for public consultation [9].

The main implementation risks were the result of the infrastructure at that period - only $20-30 \%$ of GP had a computer in their practices, they had limited access to the Internet, and there were weak skills of working with information technologies [10, 11]. Obstacles that can evoke public resistance to the system implementation were mentioned: accountability achieved by informatics systems can cause doctors' dissatisfaction because everyone could see how many patients have been cured and how much money received. And secondly, patients can be worried about the confidentiality of their personal information [12].

Publicly expressed risks and doubts about E-health have not stopped the process and guidelines were accepted by the Cabinet of Ministers on August 17, 2005. To provide further development of the system during the next four years monetary funding was granted in amount of $400000 \mathrm{LVL}$. In accordance with the guidelines E-health project was a long term project, planned to be developed from 2006-2016 and with the total amount of funding approximately 25 million LVL. Concept consisted of a common EHR system that included electronic patient data, information about clinical data treatment - orders and results of visits to specialists, laboratory and radiology results as well as designated treatment. The other modules were: E-prescription, E-administration, E-booking, Telemedicine, E-services and different types of data exchange with authorities [13, 14].

The next step in the implementation process was to develop a detailed plan of implementation activities with the deadline June 1, 2006 [13]. In accordance with the state budget for year 2006, 600000 LVL were assigned for E-health activities [15].

After the guidelines were accepted new obstacles were identified in the society - low income of the medical staff could lead to the situation that efficiency benefits declared in Ehealth concept would not be achieved, because for institutions it would be cheaper to hire some more employees working with paper-based process than to involve modern technologies and upgrade employees' information technology skills. Doubts that introduction of technical support can lead to negative impact in the treatment process, i.e., reducing direct contact between the patient and the specialist [16].

The implementation plan was not developed by the original deadline and was extended to March 1, 2007 [17]. The plan for the period 2008-2010 was developed and accepted by the Cabinet of Ministers on October 24, 2007. To provide planned activities, the required amount of funding was 29.6 million LVL. The state budgetary funding was granted in the year 2007 in the amount of $681800 \mathrm{LVL}$. The other funding sources were expected to be obtained from European Union Funds and private investors [18].

At the end of 2007 the Ministry of Health carried out a project to improve skills and knowledge of computer and the Internet use for more than 100 medical specialists [19]. 
In accordance with the guidelines there were tasks that had to be achieved by the year 2008: $60 \%$ of healthcare institutions use EHR according to common data standard (but there was even no such standard approved till March 11, 2014) and implemented central EHR system (in reality there was even no responsible authority till March 11, 2014 and there was lack of equipment and software till August, 2009) [13, 20, 21].

The main causes for the implementation delay in the period 2004-2008 as stated in the State Audit Office review are delayed development of implementation activities, large scale project with unclear scope, no funding provided for the project development, no regulatory framework. The main reasons for that were weak governance by the Ministry of Health, no compliance with the stated control plan, no risk mitigation plan, inefficient use of resources [22].

In 2008 infrastructure had changed and according to the European Commission research: internet infrastructure conforms to an average European level, $88 \%$ of GP practices use personal computer and $85 \%$ of GP have access to the Internet [23].

Year 2009 was a breakout year in E-health implementation because the project funding from the European Union was obtained, the purchase tender for equipment and technology necessary for data processing and storage for developing E-health platform was announced [21,24]. The hindering factor in 2009 was the change of the institution responsible for E-health implementation. Due to institutional reform a new institution was established - Health Economy Centre and responsibility of E-health development was transferred to the newly established institution [25].

In 2010 all previously accepted pilot projects were developed and available to residents. Patients' access to data of healthcare services paid by the state uncovered problems of accountability in GP practices - there were cases when services were declared by GP while patients reported that they did not use or get the service [26]. Transparency and accountability provided by this service showed the problem that was declared as a risk of Ehealth implementation in early 2004, i.e., that doctors could be against the system because everyone could see what services have been promoted and paid for.

In 2010 Health Economy Centre announced that a significant obstacle in the further system development was the lack of normative regulation on data and process. The work on normative regulation was started in the Ministry of Health, but due to institutional changes further development of regulations was put on hold, so Health Economy Centre had to start work on regulation from the very beginning [27].

In 2010 two tenders were announced: for Electronic Patient Data system development which was successful, but the tender result on E-prescription was contradicted and successful result of tenders was achieved only in November, 2011. Failures in tenders led to hinder the whole development process and originally planned tests of designed system were changed several times [28-31].

In autumn 2011, the responsible authority was changed again - two previously existing institutions Health Account Centre and Health Economic Centre were merged in the National Health Service [32].

The regulatory framework draft on processing Health data was developed and in July, 2012 was opened for public discussions [33]. New technical risks arose - there were different IT systems used in healthcare institutions and to promote the system integration investments had to be made in commercial systems. This led to actions against E-health implementation because of the expenses to manage systems already used [34-36].

The regulatory framework on processing Health data was confirmed only on March 11, 2014 [20]. Only from this date there was a clear vision on responsibilities, data exchange standard, requirements for secure data process and storage.

In 2015 the debates on E-health became more active - doubts rose in the society about successful implementation. The risk of losing ERAF funding arose due to the approaching 
project deadline and the lack of system implementation [37]. The State Audit Office report awoke dissatisfaction in the government and society about the project - announcing that during nine years 14.5 million EUR were spent, but none of the services was available $[22,38,39]$ Third round of E-health project development process started by ensuring ERAF funding in amount of 36 million EUR [40].

Six month before compulsory use of E-health system, Latvia Hospital Association asked the Ministry of Health to change the date of compulsory use and give six-month period, because of technical difficulties of hospital IT systems to provide data exchange with E-health [41]. At the same time GP raised pressure in media about doubts on system quality, patient data security and changes in their daily practice. In response to that compulsory date of E-health use was changed to December 1, 2016 [42, 43].

Finally in 2016 E-health system was developed and there were no risks of losing ERAF funding [44]. In the summer E-health portal was available to residents [45]. According to National Health Centre information by October, 2016 there were more than 3000 specialists that had attended special programmes and had been educated in work with E-health and the training process will be continued [46]. On October 26, 2016 the Minister of Health announced that E-service "Data on incapacity to work" is working properly, but Eprescription need to be improved and could be used voluntarily [47]. One of the biggest pharmacy networks "BENU" announced that their systems were ready to use Eprescriptions [48]. On October 28, 2016 the E-prescription project was successfully implemented: E-prescription was drawn up in one of the leading hospitals - PSKUS and the medicine was received in BENU pharmacy based on E-prescription [49].

E-health was designed and implemented before the compulsory use date - December 1, 2016. But due to earlier protests of GP associations and a call to sabotage contract signing on E-health use, there were doubts about the possibility of patients to be able to register their incapacity to work through their GP, because by November 1, 2016 only 260 agreements were signed [50-52]. As a result, the Ministry of Health initiated the change of the date of E-health system compulsory use [53].

According to data of the Ministry of Health by November 29, 2016, 45 records on incapability to work and 21 E-prescription have been discharged. The Cabinet of Ministers accepted the initiative to shift compulsory use of E-health system to July 1, 2017. But on the mentioned date, not only those two services: E-prescription and Data on incapability to work have to be used, but also a plenty of other services - referrals to get ambulatory or stationary service, responsibility to register in E-health system results and reviews of consultation and treatment process as well as other information of treatment process and documentation $[54,55]$.

\section{Analysis of interest group activities during E-health implementation}

Implementation of E-health system has an impact on patients, medical staff, healthcare institutions, pharmacy and health insurance companies as well as institutions that govern healthcare policy. Interest groups in Latvia which represent those affected groups are:

1. Patients - patient organisations and the Patients' Ombudsman Office.

2. Medical staff - professional organizations of doctors which are widely known Association of Doctors, two Associations of General Practitioners, The Union of Health and Social Care Employees of Latvia.

3. Healthcare institutions - Latvia Hospital Association.

4. Pharmacy - Pharmacy Owners' Association and Pharmacists' Society of Latvia.

5. Health insurance companies are represented by Latvian Insurers Association. 
According to publicly accessible information and the State Audit Office review, during the policy formation process interest groups mentioned above were not engaged in the process. Only interests of one of the groups was represented in this process - employees of the Ministry of Health and institutions which are subordinated to the Ministry of Health, i.e., healthcare policy developers, executers, managers and administrators [22].

During the long implementation process which started in 2004, the first opinions publicly expressed by interest groups appeared only in 2010. At that time there were debates in the government about the progress of E-health implementation and doubts were expressed about risks that the system would not be implemented [57].

For more than five years during which the work in E-health implementation was in progress, there was no discussion in the society and interest groups were inactive, that can be explained by the lack of information on the reform as well as by the fact that interest groups were not engaged in the processes.

The interest group that shows strong support to E-health implementation is pharmacy represented by Pharmacy Owners Association. They understand the benefits of the system the system will ensure a possibility to control accurate and proper use of medicine and using E-prescription will decrease bureaucratic burden on pharmacists' daily work. The system implementation will also decrease the number of cases when there are mistakes in prescriptions and pharmacists have to contact the specialist to find out the reason for the mistake [58].

Pharmacies were ready for E-health implementation from January 1, 2016. Delay of compulsory use of the system led to disappointment because their systems were adapted to use E-health with the new normative regulation. As E-health compulsory use date was changed, but normative regulation was not changed, pharmacies had to change their system again [59]. The other interest groups representing pharmacy - pharmaceutical industry and pharmacists had not been active in E-health discussions.

The other group that supports E-health implementation is private insurance companies. The problem that insurance companies have and which implementation of E-health system could resolve is that different systems that healthcare service providers use are not connected, so a patient can go and have analysis and treatment in one healthcare institution today and the same service or treatment in another institution next day. As the result, this can lead to unnecessary treatment episodes that are paid for twice - by the state and the insurer, thus being ineffective [60].

The interest group that had a neutral attitude to E-health implementation was healthcare service providers - hospitals and health care centres. Their only doubts were - how the systems already used in their institutions could maintain requirements to provide data exchange with centralised E-health system [61]. Healthcare institutions had a neutral attitude, but in comparison to pharmacy, they were not ready to implement E-health on the planned date - January 1, 2016.

Interest groups that showed the discountenance to E-health implementation were representatives of the medical staff. The first criticism came from the Chairman of the Board of the Association of Doctors who implied that development of E-health is for pharmacy and software developer interests, but not in patients' interests [62].

The other institution protecting the rights of the medical staff - The Union of Health and Social Care Employees of Latvia in August, 2012 asked The Minister of Health to stem the implementation of E-health system since medical data of patients that will be collected in the centralised system poses a risk to the protection of those data [63]. When GP called to sabotage the system, the union expressed their support, indicating that implementation of unfamiliar system in a compulsory mode will threaten working environment, and that the use of E-health has not only benefits, but has also side effects like burnout syndrome to medical staff, less time dedicated to patient and hindering of all working process [64]. 
The most resistant to E-health implementation are interest groups representing GP. They mention different obstacles according to which the system should not be implemented or should be used voluntarily, not compulsory:

- For practising GP who has not grown up in E-environment, data input in electronic ambulatory patient card during the consultation process is cumbersome and timeconsuming. So they will still use paper based process and somebody will input those data electronically in the system afterwards which leads to double work and is not effective [34].

- Practices of GP are not technically ready to use information technologies as there are still practices without a computer, especially in rural areas - there are some doctors who use library computers to input data needed for the National Health Service. There is also uncertainty of computer using skills, especially in the group of elderly GP - about $10 \%$ of GP are of the retirement age and the pressure to use E-health can lead to the situation that doctors decide to leave their practice and retire $[43,65]$.

- There are doubts about patient data security. GP are confused about data confidentiality that has to be kept between the patient and the doctor, but the ability to get data from E-health will be promoted for other institutions as well, for example, Health Inspectorate $[42,50]$.

- GP are not familiar with developed E-health system, so they are concerned about how the system will work and how it will impact their daily practice and relations with their patients [51].

Associations of GP not only expressed their doubts publicly, but also called their members to sabotage the implementation of the system by not signing the contracts of the system use $[42,51]$.

After the interest group expressed its opinion, doubts about threats to patient data security, the hindering of the whole working process in practices and threat that about $10 \%$ of GP could leave their practices in the existing conditions, where there is already shortage and unmet needs for GP in rural areas - those activities raised an uproar in the media and pressure in the society. Their activities led to change the date of compulsory use of E-health system twice - first time, when the Minister of Health Guntis Belēvičs initiated date change from January 1, 2016 to December 1, 2016, and second time - when the Minister of Health Anda Čakša initiated date change to July 1, 2017.

\section{Conclusions}

Results of research on E-health implementation process in Latvia showed that during the period 2005-2015 the main reasons for inability to implement the system was weak project governance and that only from 2015 there had been an impact of interest groups on the implementation data delay.

The main conclusion which the State Audit Office announced in their review was that the Ministry of Health had not worked efficiently enough on E-health implementation process supervision and control [22]. Also the current Minister of Health publicly announced that in the E-health implementation process there were a lot of omissions that are still observed today and there have been a lot of inappropriate decisions made [56].

Representatives of impacted interest groups were not involved in the policy formation process - neither in developing guidelines nor in the implementation plan or acceptance test process. 
Interest groups whose members will be affected by the implementation of E-health system have been active only in the last phase of the implementation. Patients and pharmacy industry did not take part in the process at all.

Interest groups that showed strong support to E-health implementation were pharmacy owners and private insurance companies. That can be explained by two reasons: first - in most pharmacies and insurance companies some kinds of information technology systems are used, so the pharmacists and insurance companies are familiar with the use of personal computer in their daily practice. And the second - pharmacy owners and insurance companies know about the benefits they will gain from E-health and those benefits will directly improve and facilitate their work.

The neutral attitude of healthcare providers can be explained by the same reasons as in previous cases - they are familiar with information technology use in their institutions and know about benefits in accountability and transparency the systems can provide. For the healthcare institutions there are no clear benefits they will gain by implementing E-health. This could be the reason why they didn't hurry to invest resources in the system change to improve compatibility with E-health.

Interest groups that discounted and even sabotaged the implementation process were organizations which represent the interests of doctors. According to the previously mentioned counteraction purposes, the main reasons are - no information about data processing mechanisms and no information about benefits the doctors will gain from the implementation of the system. Another reason is the lack of education and training, using computer and information technologies, unfamiliarity with the new system that has to be used.

The counteraction could have been less if interest groups would have been involved in the developing process from the early beginning. As showed the experience of Estonia Ehealth implementation - from the point when GPs were involved in the development process and there were information and training campaigns carried out, the resistance to the new system noticeably decreased [66].

The research showed that interest groups involved in healthcare in Latvia are active they use lobbying strategies and have significant impact on healthcare development and change implementation.

Although the presence of interest groups in political activities conforms to a democratic governance, because of the weak governance of E-health system by the Ministry of Health and lack of involvement of the main interest group in the policy forming, development and implementation planning process, the result was that interest groups did not act internally they did not cooperate with the government institutions to create policy that meets the needs of the society, but their activities were only external - they acted just like disincentive to the policy implementation.

Result of the absence of a constructive cooperation between authority and interest groups acting in healthcare is that the implemented changes in the healthcare system do not conform to a long term development policy, but are chaotically made according to a lobbied demand without assessment how the change will impact the whole system and the society.

\section{References}

1. Special Assignments Minister for Social Integration Affairs of Latvia. Policy Guidelines for Strengthening Civil Society 2004-2015

2. Society Integration Foundation. Grant scheme "Strengthening civil society and promotion of the integration of society" source of Funding "EEA Financial Mechanism 2004-2009" 
3. B.G. Peters. Institutional Theory in Political Science. The "New Institutionalism., Contiinum Londond and New York (2000)

4. G. Jordan and W.A. Maloney. Democracy and Interest Groups. Enhancing Participation? Palgrave Macmillan (2007)

5. H. Kluver. Lobbying in the European Union. Interest Groups, Lobbying Coalitions, and Policy Change. Oxford University Press (2013)

6. Y. Yishai. Participatory Governance in Public Health: Choice, but no Voice. Oxford Handbook of Governance, Oxford University Press (2012)

7. R.M. Kaplan and Y.M. Badad. Balancing influence between actors in healthcare decision making. BMC Health Services Research. DOI: 10.1186/1472-6963-11-85 (2011)

8. Veselības ministrija. Rīkojums Nr.302 "Par darba grupas izveidi e-veselības attīstības stratēgijas izstrādāšanai”" (03.11.2003)

9. A. Ādamsone. Sabiedrību aicina izteikt viedokli par e-veselības pamatnostādñu projektu, LETA (14.06.2004)

10. A. Ādamsone. Ģimenes ārsti: Tikai neliela daļai ārstu prakšu nodrošinātas ar datoriem, LETA (02.02.2005)

11. A. Ādamsone. Moderno IT ieviešanu veselības jomā kavē vairāki faktori, LETA (07.04.2005)

12. L. KL̦aviņš. Microsoft Latvia pārstāvis prognozē grūtības veselības aprūpes sistēmas datorizācijā, LETA (10.03.2005)

13. Ministru kabinets. Rīkojums Nr.560 "Par pamatnostādnēm "e-veselība"Latvijā" (17.08.2005)

14. Veselības ministrija. Pamatnostādnes "e-veselība Latvijā" (informatīvā daļa) (17.08.2005)

15. A. Ādamsone. "E-veselības” plānu ìstenošanai nākamgad atvēlēti 600000 latu, LETA (31.12.2005)

16. A. Ādamsone. Informācijas tehnologiju plašāku izmantošanu veselības aprūpē var kavēt vairāki škērṣ̌ıli, LETA (21.08.2005)

17. Ministru kabinets. Rīkojums Nr.430 "Grozījums Ministru kabineta 2005.gada 17.augusta rīkojumā Nr.560 "Par pamatnostādnēm "e-Veselības Latvijā" (09.06.2006)

18. Ministru kabinets. Rīkojums nr. 660 "Par pamatnostādņu “e-Veselība Latvijā"̄stenošanas plānu 2008.-2010.gadam (24.10.2007)

19. S. Sproğe. Veselības aprūpes speciālistus reǵionos apmācīs darbam ar datoru., LETA (06.12.2007)

20. Ministru Kabinets. Noteikumi Nr.134 "Noteikumi par vienoto veselības nozares elektronisko informācijas sistēmu” (11.03.2014)

21. I. Mežiniece. E-veselības projekta ieviešanas iekārtām tērēs Ls 58 122., LETA (16.08.2009)

22. Latvijas Republikas Valsts Kontrole. Revīijijas ziņojums: Vai projekts "E-veselība Latvijā" ir solis pareizajā virzienā. Lietderības revīzija "Informācijas sistēmas veselības aprūpē", Rīga (2015)

23. L. Grundule. Pètījums: Latvijā elektroniskie pakalpojumi veselības aprūpes jomā tiek izmantoti ierobežotā apjomā. LETA (25.04.2008)

24. I. Mežiniece. VM plāno izstrādāt pilotprojektus vairākiem e-veselības pakalpojumiem, LETA (14.01.2009)

25. Ministru kabinets. Noteikumi Nr.1110 Veselības ekonomikas centra nolikums (29.09.2009)

26. I. Mežiniece. Gavars ar atbildīgajām institūcijām pārrunās ar e-veselību saistītus jautājumus, LETA (15.09.2010) 
27. K. Pots. Ieviest "e-veselību"traucē normat̄̄vā regulējuma neesamība", LETA (18.06.2010)

28. K. Pots. Veselības ekonomikas centrs pirks konsultācijas par 107000 latiem; “ereceptes" izstrādes konkurss pārsūdzēts. LETA (16.11.2010)

29. K. Pots. VEC “e-veselības” izstrādei slēelz līgumus par 2.96 miljoniem latu”, LETA (01.03.2010)

30. LETA. E-receptes informācijas sistēmu izstrādās "In-Volv Latvia” un "ABC software", LETA (22.12.2011)

31. K. Miḷūna. E-veseslības sistēmas testēšanu ar reāliem pacientu datiem sāks decembrī, LETA (17.10.2012)

32. Ministru Kabinets. Noteikumi Nr. 850 "Nacionālā veselības dienesta nolikums" (01.11.2011)

33. D. Kḷanska. Nodrošinās centralizētu pacientu veselības informācijas uzglabāšanau, LETA (17.07.2012)

34. E. Rutule. Ministrija: Medicīnas nozarē izmanto dažādas IT sistēmas, bet to salāgošanaiar e-veselības portālu būs pārejas periods, LETA (05.12.2012)

35. A. Ādamsone. Apdrošinātāji cer uz e-veselības ieviešanu, LETA (10.10.2013)

36. A. Sauka. ARS vadītājs: Ieviešot e-veselību, bütu jāparedz valsts līdzekļi privāto sistēmu salāgošanai ar valsts sistēmu, LETA (04.04.2015)

37. K. Pētersons. NVD vadītāja: Nepastāv risks, ka Latvijā neizdosies ieviest e-veselības sistēmu, LETA (11.05.2015)

38. E. Valtmane. Valsts kontrole informès par e-veselības sistēmas revīzijā konstatēto, LETA (07.09.2015)

39. E. Valtmane. VK:Valstij var nākties apmaksāt neizdevušos e-veselības projektu, LETA (08.09.2015)

40. K. Pētersons. Nesaņemot papildus lìdzeklus e-veselības ieviešanai, VM projekta ieceres realizes mazā $k \bar{a}$ apjomā, LETA (08.09.2015)

41. K. Pētersons. Pirmajā pusgadā ārstniecības iestādes e-veselības sistēmu tomēer varēs lietot brīvrātīgi, LETA (16.09.2015)

42. LETA. Ģimenes ārsti valdību lugs aicināt pārstrādāt e-veselības projektu; gatavojas neslēgt līgumus par tās lietošanu, LETA (28.11.2015)

43. K. Pētersons, E. Valtmane. Pēc plašām diskusijām valdība vienojas e-veselības sistēmas ieviešanu atlikt uz gadu., LETA (01.12.2015)

44. K. Pētersons. NVD tomēr izdevies izstrādāt e-veselības projektu, un drīzumā sistēmas lietošana tiks piedāvāta ārstniecības iestādēm, LETA (04.01.2016)

45. K. Pētersons. Darbu sācis e-veselības portals, LETA (02.07.2016)

46. K. Pētersons. NVD organizes seminārus veselības nozares speciālistiem par eveselības sistēmas ieviešanas aktualitātēm, LETA (12.10.2016)

47. LETA. Čakša: Elektroniskā slimības lap air gatava darbam; ar e-recpti sarežğìt āk, LETA $(26.10 .2016)$

48. A. Sauka. "BENU aptiekas"sāk e-recepšu apkalpošanu, LETA (27.10.2016)

49. Preses relīze. Aptiekā izsniegtas zāles pret pirmo e-recept., LETA (28.10.2016)

50. K. Pētersons. Bažĭjoties parpacientu datu aizsardzību un savām iespējām strādāt ar e-veselību, gimenes ārsti sistēmai vēlas pievienoties brīvprātīgi, LETA (04.03.2016)

51. A. Antanoviča. Ģimenes ārstu asociācija vienojas neparakstīt līgumus par eveselības sistēmas izmantošanu, LETA (21.10.2016)

52. K. Pētersons. NVD: Parakstī̌sanas procesā ir 2100 līgumi par e-veselības lietošanu, kas ir vairāk kā puse no plānotā., LETA (01.11.2016)

53. K. Pētersons. Čakša rosinās pagarināt laiku, kurāa ārsti brīvprātīgi varēs lietot gan e-recepti, gan darbnespējas lapu, LETA (08.11.2016) 
54. K. Pētersons. NVD noslēdzi 733 līgumus par e-veselības lietošanu, tai skaitā 128 ar gimenes ārstiem, LETA (29.11.2016)

55. Ministru Kabinets. Noteikumi Nr.748 "Grozījumi Ministru kabineta 2014.gada 11.marta noteikumos Nr. 134 "Noteikumi par vienoto veselības nozares elektronisko informācijas sistēmu”, LETA (29.11.2016)

56. K. Pētersons. VM sākusi pārbaudi saistībā ar e-veselības informācijas sistēmu ieviešanu, LETA (08.11.2016)

57. E. Kozule. Saeimas komisijā vērtēs e-medicīnas ieviešanas progresu un lietderību, LETA (17.02.2010)

58. A. Blumberga. Latvijas farmaceiti pozitīvi vērtēe e-recepšu ieviešanu, LETA (02.04.2010)

59. A. Sauka. Asociācija: E-veselības neieviešanas dēl aptiekām būs jāatliek IT sistēmu modernizācija; pieaugs rindas, LETA (01.12.2015)

60. A. Ādamsone. Mudina nodrošināt labāku caurskatāmību un racionālāku resursu izmantošanu veselības aprūpē, LETA (21.07.2012)

61. A. Sauka. ARS vadītājs: Ieviešot "e-veselību”, būtu jāparedz valsts lìdzekļi privāto sistēmu salāgošanai ar valsts sistēmu, LETA (04.04.2015)

62. K. Pots. Apinis: "E-veselības” projektu ìsteno biznesa, nevis pacientu interesēs, LETA (02.06.2010)

63. K. Mil̄ūna. Mediķu arodbiedrība aicina apturēt VM izstrādāto e-veselības projekta virzību, LETA (07.08.2012)

64. K. Pētersons. Mediķu arodbiedrība atbalsta ǵimenes ārstu lèmumu neparakstīt lìgumu par e-veselības sistēmas izmantošanu, LETA (24.10.2016)

65. K. Pētersons. Guimenes ārsti aicina e-veselības ieviešanai noteikt sě̌u mēnešu izmēginājuma periodu, LETA (08.11.2016)

66. A. Kinca. Reportāža no Igaunijas: Kopš e-veselības ieviešanas papīra kaudzes ārstu kabinetos aizstāj dators, LSM (19.11.2016) 